\title{
Két hazai kétéltüfaj kitridiomikózissal szembeni fogékonysága és érzékenysége
}

\author{
Drexler Tamás ${ }^{1,2}$, Ujszegi János ${ }^{2}$, Németh Z. Márk ${ }^{3}$, Vörös Judit ${ }^{4}$ és \\ Hettyey Attila ${ }^{2}$ \\ ${ }^{1}$ Ökológia Tanszék, Biológiai Intézet, Állatorvostudományi Egyetem, \\ 1078 Budapest, Rottenbiller u. 50. \\ ${ }^{2}$ Lendület Evolúciós Ökológiai Kutatócsoport, Növényvédelmi Intézet, Agrártudományi \\ Kutatóközpont, Magyar Tudományos Akadémia, \\ 1022 Budapest, Herman Ottó út 15. \\ ${ }^{3}$ Növénykórtani Osztály, Növényvédelmi Intézet, Agrártudományi Kutatóközpont, Magyar \\ Tudományos Akadémia, \\ 1022 Budapest, Herman Ottó út 15. \\ ${ }^{4}$ Magyar Természettudományi Múzeum, \\ 1088 Budapest, Baross u. 13. \\ e-mail:dretom93@gmail.com
}

\begin{abstract}
Összefoglaló: A kétéltűeket veszélyeztető kitridiomikózis kórokozója, a Batrachochytrium dendrobatidis (Bd; Longcore, Pessier \& D. K. Nichols, 1999) nevü gombafaj bizonyítottan jelen van a Kárpát-medencében is, ugyanakkor a számlájára írható drasztikus állománycsökkenést itt ez idáig nem tapasztaltunk. Ennek egyik oka lehet a honos populációk magas toleranciája a betegséggel szemben. Kísérletünkben barna varangy és erdei béka ebihalait fertőztük egy magas virulenciájú Bd törzzsel. A gomba egyik fajnál sem csökkentette a túlélést, a fejlődési sebességet és az átalakulás utáni tömeget. Ugyanakkor a barna varangy egyedeknél az erdei békáknál mért fertőzöttség sokszorosát figyeltük meg. Úgy tünik, hogy a hazai barna varangy populációk magas toleranciával, az erdei béka populációk pedig magas rezisztenciával rendelkeznek a betegséggel szemben.
\end{abstract}

Kulcsszavak: kitridiomikózis, barna varangy, erdei béka, tolerancia, rezisztencia

\section{Bevezetés}

A kitridiomikózis a legjelentősebb kétéltủeket fertőző betegség, mely az utóbbi évtizedekben szerepet játszott világszerte több, mint 200 faj állománycsökkenésében (Skerratt et al. 2007), korábban érintetlen fajok veszélyeztetetté válásában, bizonyos fajok lokális és teljes kipusztulásában (Mendelson et al. 2006, Van Rooij et al. 2015). A Batrachochytrium dendrobatidis (továbbiakban Bd) nevü rajzóspórás 
gombafajt 1998-ban írták le és azonosították, mint a betegség kórokozóját, azóta az összes kontinensen megtalálták, ahol kétéltüek is előfordulnak (Berger et al. 1998, Van Rooij et al. 2015).

A Bd Európa számos országában megtalálható, eddig azonban csak Spanyolországban mutattak ki hozzá köthetö jelentős állománycsökkenést (Bosch et al. 2001, Baláž et al. 2014). Hazánkban eddig gyepi békától (Rana temporaria Linnaeus, 1758), zöldbékáktól (Pelophylax komplex fajai) és sárgahasú unkától (Bombina variegata Linnaeus, 1758) származott pozitív minta (Baláž et al. 2014). Utóbbiról sikerült izolálni a gomba hazai változatát, mely a Spanyolországban jelentős pusztulást okozó BdGPL törzs leszármazottja, viszont laboratóriumi kísérletek ezzel az izolátummal még nem történtek.

A Bd széles gazdaspektrummal rendelkezik, jelenleg 1252 vizsgált fajból 520ból sikerült kimutatni (http1). Arról azonban kevés információ áll rendelkezésre, hogy mi okozza a különböző régiók populációi közötti eltéréseket a betegség súlyosságában (Kilpatrick et al. 2010, Van Rooij et al. 2015). Ennek hátterében állhatnak az élőhelyre jellemző környezeti tényezők, a lokálisan jelen lévő Bd törzs kórokozó tulajdonságai (infektivitás és virulencia) és a gazdafaj érzékenységbeli sajátosságai (rezisztencia és tolerancia), erre vonatkozó ismereteink azonban rendkívül korlátozottak (Woodhams et al. 2011).

Kísérletünkben két gyakori hazai faj, a barna varangy (Bufo bufo Linnaeus, 1758) és az erdei béka (Rana dalmatina Fitzinger, 1839) egyedeinek ellenállóképességét tanulmányoztuk korai életszakaszban egy Spanyolországban izolált, magas virulenciájú Bd törzzsel szemben. A fertőződés mértéke mellett vizsgáltuk a Bd jelenlétének lehetséges letális és/vagy szubletális hatását a fó életmenet-változókra.

\section{Módszerek}

Kisérleti állatok és tartási körülmények

Vizsgálatainkhoz erdei béka és barna varangy petéket gyüjtöttünk fajonként 9-9 petecsomóból a Visegrádi-hegység egyik kisvizéből, melynek környékén a Bd jelenléte bizonyított (Baláž et al. 2014; Apátkúti völgy; N 47,767058, E $18,981325^{\circ}$ ).

A kelés után az ebihalak közül fajonként 54, egészségesnek látszó egyedet kiválasztottunk, a fel nem használtakat pedig szabadon engedtük a gyüjtés helyszínén. Az állatokat egyesével tartottuk 1 liter RSW-vel (Reconstituted Soft Water, APHA 1985) feltöltött müanyag dobozokban és ad libitum etettük spenóttal, melyhez er- 
dei békák esetén egy tömegszázaléknyi Spirulina algaport adtunk. A varangyoknál egy korábbi kísérletben magas mortalitást tapasztaltunk Spirulina jelenlétében, amit a tartóvízben történő baktérium-túlszaporodás okozhatott az algapor és a Bd tápleves interakciójának hatására, ezért ebben a kísérletben a varangy ebihalak nem kaptak Spirulinát. Az ebihalak tartóvizét hetente kétszer cseréltük. A mellső lábak megjelenésekor (42-es fejlettségi állapot; Gosner 1960) a vizet $100 \mathrm{ml}$ tiszta RSW-re cseréltük, a tartódobozt lefedtük és kb. $10^{\circ}{ }^{\circ}$-os szögben megdöntöttük, így száraz és vízzel borított részt egyaránt biztosítva az állatoknak. Az átalakult egyedeket (farok teljesen eltünik; 46-os fejlettségi állapot; Gosner 1960) új, lefedett, de jól szellőző, búvóhellyel ellátott dobozba helyeztük, melynek alját nedves papírtörlővel béleltük. Az erdei békákat frissen kikelt napostücskökkel (Acheta domestica, Linnaeus, 1758), a barna varangyokat kisebb méretük miatt ugróvillásokkal (Folsomia spp.) ad libitum etettük. A kísérlet klimatizált helyiségben (hömérséklet: $19,4{ }^{\circ} \mathrm{C} \pm 0,7$; átlag $\pm \mathrm{SD}$ ), a természetes világos-sötét szakaszokhoz igazított mesterséges megvilágítás mellett zajlott, a vonatkozó karantén szabályok szigorú betartása mellett.

\section{A Bd tartása és a fertözés körülményei}

Kísérletünkhöz a Bd GPL törzs IA042 izolátumát használtuk. A törzstenyészetet folyékony mTGHL táplevesben $4{ }^{\circ} \mathrm{C}$-on tartottuk. A fertőzések előtt 100-szoros hígítást készítettünk, amit egy héten át $20^{\circ} \mathrm{C}$-on inkubáltunk. Közvetlenül a fertözés előtt Bürker-kamra segítségével állítottuk be a zoospóra (zsp) koncentrációt. Háromféle kezelést alkalmaztunk: kontrol $(0 \mathrm{zsp} / \mathrm{ml})$, alacsony $(\sim 10 \mathrm{zsp} / \mathrm{ml})$, és magas ( $1000 \mathrm{zsp} / \mathrm{ml})$ zsp-koncetrációt. A magas zsp-koncentrációjú kezeléshez az egy hét alatt felszaporodott tenyészetet, az alacsonyhoz annak 100-szoros hígítását használtuk. Az állatok tartóvizét minden vízcserét követően újrafertőztük 1 $\mathrm{ml}$, a kezeléseknek megfelelő koncentrációjú tenyészettel. A kontrollcsoport azonos mennyiségü steril táplevest kapott. Mindkét fajt nagyságrendileg azonos dózissal fertöztük (1600-2100 zsp/ml a magas koncentráción, attól függően, hogy az inkubáció alatt mennyire szaporodott el a Bd a tenyészetben). Az ebihalak tartódobozait a kezelések alapján térbeli blokkokon belül randomizálva helyeztük el a polcokon. Az állatok túlélését naponta monitoroztuk. Feljegyeztük a mellső lábak megjelenésének és a farok teljes mértékü felszívódásának időpontját, és utóbbitól számítva még két hétig tartottuk őket. A kísérlet végén megmértük az egyedek tömegét (Ohaus Pioneer PA-114 analitikai mérleggel, milligramm pontossággal), túlhütéssel feláldoztuk ( 30 percig $4{ }^{\circ} \mathrm{C}$, majd egy napig $-20{ }^{\circ} \mathrm{C}$ ), majd $70 \%$-os etanolban konzerváltuk őket. 


\section{A Bd kimutatása}

A fertőzés intenzitását kvantitatív PCR (qPCR) segítségével mértük. A qPCR-hez a mintákat a hátsó végtag ujjainak levágásával nyertük, amikből a DNS-t szilika gyöngyök és $50 \mu 1$ PrepMan Ultra (Life Technologies) felhasználásával vontuk ki. A qPCR reakciókat BioRad CFX96 Touch Real-Time PCR System gépen végeztük, 2x TaqMan Universal PCR Mastermix-et (Life Technologies) alkalmaztunk a Boyle és munkatársai (2004) által közölt protokoll szerint. Minden mintából két párhuzamos mérést végeztünk és a standardot négy hígításban használtuk (100, 10, 1 és 0,1 genom-ekvivalens (GE) / $\mathrm{ml}$ ).

\section{Statisztikai elemzések}

A Bd GE adatokat rangtranszformáltuk, mert előfordultak közöttük a 1-1000 GE/ $\mathrm{ml}$ intervallumon kívül eső értékek is, melyek mennyiségileg nem tekinthetők 100\%-ig megbízhatónak, mivel a standard kalibrációs görbén kívül esnek. A fejlődés hosszát a mellső végtagok megjelenéséig (42-es fejlettségi állapot) eltelt napok számával jellemeztük. A szubletális hatások vizsgálatánál csak a kísérlet végéig túlélt állatok adatait elemeztük.

A fertőződés mértékét Wilcoxon-féle előjeles rangpróbával vizsgáltuk aszerint, hogy a kezelési csoportok fertőzöttsége eltér-e a kontrollcsoport fertőzöttségének megfelelő 0 -s várható értéktől. A kezelések testtömegre gyakorolt hatását általános lineáris modellekkel (GLM) vizsgáltuk, amibe a kezelést faktorként, az átalakulásig eltelt napok számát pedig kovariánsként vittük be. Barna varangyoknál a tömeg adatokat log-transzformáltuk, hogy teljesüljön a varianciák homogenitásának feltétele.

A kezelésnek az átalakulásig eltelt idő hosszára kifejtett hatását varangyoknál GLM-el, erdei békáknál Kruskal-Wallis próbával teszteltük, mert utóbbi esetben a modellreziduálisok transzformáció után sem mutattak normáleloszlást, és a varianciák is különbözőek maradtak a csoportok közöttt.

Az egyedek túlélését az erdei békánál nem elemeztük statisztikailag, mert nagyon alacsony volt a mortalitás, összesen három egyed pusztult el az 54-ből (kettő alacsony, egy pedig magas Bd-koncentráción). A varangyoknál Cox-regressziót használtunk, melybe kovariánsként bevittük a fertőzöttség mértékét, fix hatásként pedig a kezelést.

Minden kiindulási modellünk tartalmazta az összes kettős interakciót, és a teljes modellből lépésenként távolítottuk el a nem szignifikáns $(P>0,05)$ tagokat. Az eltávolított változókra vonatkozó statisztikák kinyeréséhez egyesével visszaillesztettük azokat a végső modellbe. A modellek alkalmazhatóságának feltételei közül a varianciák homogenitását Levene-próbával teszteltük, a reziduumok normális eloszlását pedig QQ-ábrán ellenőriztük és Shapiro-Wilk próbával teszteltük. 
A statisztikai elemzéseket az SPSS Statistics programcsomag 17.0 verziójával végeztük, az ábrák R 3.0.3 programcsomaggal készültek.

\section{Eredmények}

\section{Erdei béka}

A magas koncentrációjú kezelés szignifikáns hatással volt a fertőzöttségre (Wilcoxon-féle előjeles rangpróba: $P=0,012$ ), míg az alacsony koncentrációjú kezelésben a fertőzöttségi intenzitás nem tért el szignifikánsan a kontrollra jellemző 0 várható értéktől $(P=0,3 ; 1$. ábra). A magas $B d$ koncentrációval fertőzött egyedek nagyobbak voltak a másik két kezelésben szereplőknél, de ez a különbség nem volt szignifikáns (GLM: $F 2 ; 48=3,12 ; P=0,053 ; 2$. ábra). A testtömegre az átalakulásig eltelt napok száma nem volt szignifikáns hatással sem önmagában, sem a kezeléssel interakcióban (GLM: átalakulásig eltelt napok: $F 1 ; 49=1,02 ; P=$ $0,3$; kezelés $\times$ átalakulásig eltelt napok: $F 2 ; 45=0,89 ; P=0,4)$. A kezelések nem befolyásolták szignifikánsan az átalakulásig eltelt napok számát (Kruskal Wallispróba: $P=1 ; 3$. ábra).

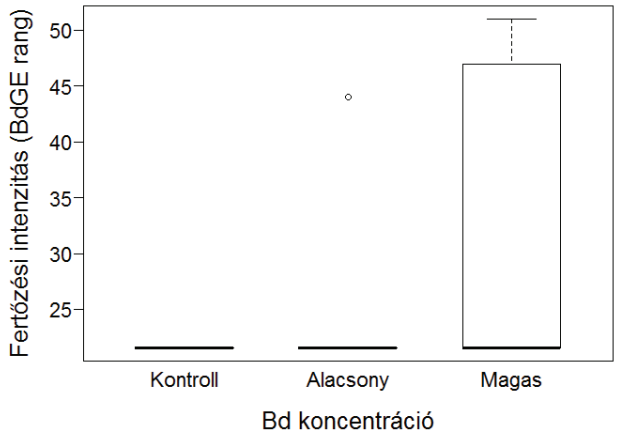

1. ábra. A kezelések hatása az erdei békák fertőződésére. Az ábrán rangok szerepelnek, a kontrollcsoport mediánja ezért nem 0 , de nem volt fertőződés ennél a kezelésnél.

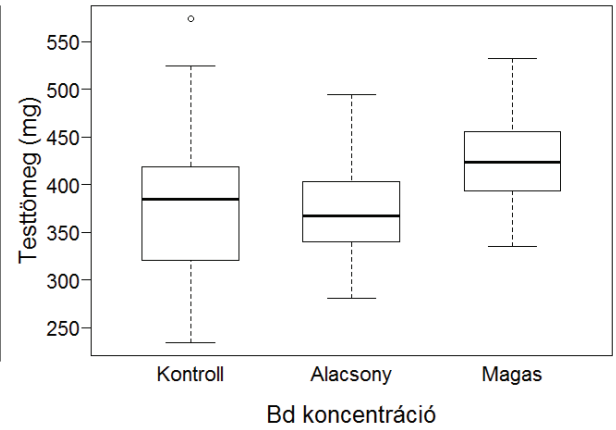

2. ábra. Az erdei békák tömege a különböző kezelésekben.

\section{Barna varangy}

Mind az alacsony, mind a magas koncentrációjú kezelés szignifikánsan növelte az egyedek fertőzési intenzitását a kontroll 0 várható értékéhez képest (Wilcoxonteszt: alacsony koncentráció: $P=0,028$; magas koncentráció: $P=0,002 ; 4$. ábra). A testtömeget a kezelések nem befolyásolták szignifikánsan (GLM: $F 2 ; 34=0,95$; $P=0,4 ; 5$. ábra), de az átalakulásig eltelt napok száma igen (GLM: $F 1 ; 36=9,87$; 
$P=0,003)$ : minél tovább tartott a fejlődés, annál kisebb volt a tömeg 14 nappal az átalakulás után. A kezelés és a fejlödés sebessége közti interakció szintén nem volt hatással a tömegre $(F 2 ; 32=0,92 ; P=0,4)$. A kezelés nem befolyásolta az átalakulásig eltelt napok számát sem (GLM: $F 2 ; 35=0,03 ; P=1 ; 6$. ábra).

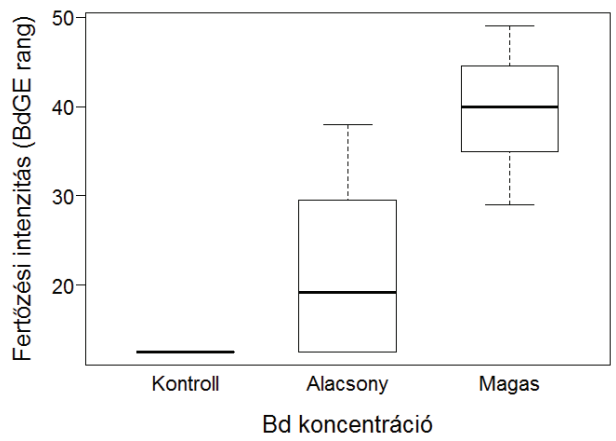

3. ábra. A kezelés hatása az erdei békák átalakulási idejére.

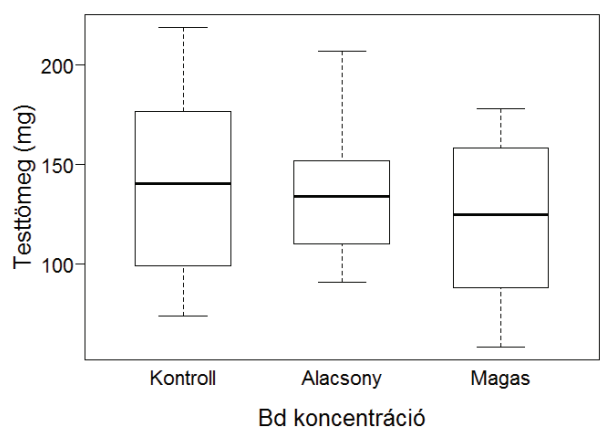

5. ábra. A kezelés hatása az átalakult barna varangyok tömegére.

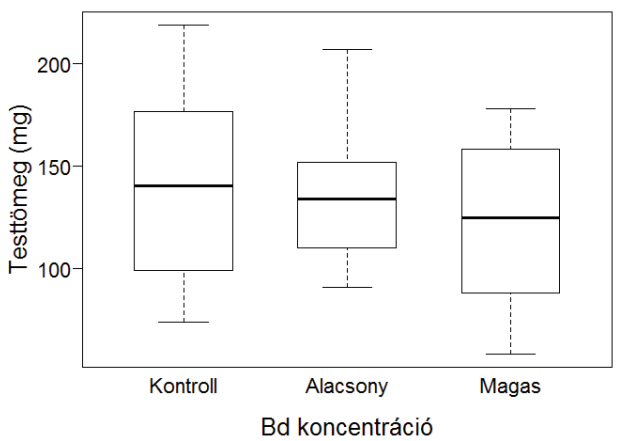

4. ábra. A kezelés hatása a barna varangyok fertőződésére. Az ábrán rangok szerepelnek, a kontrollcsoport mediánja ezért nem 0 , de nem volt fertőződés ebben a kezelésben.

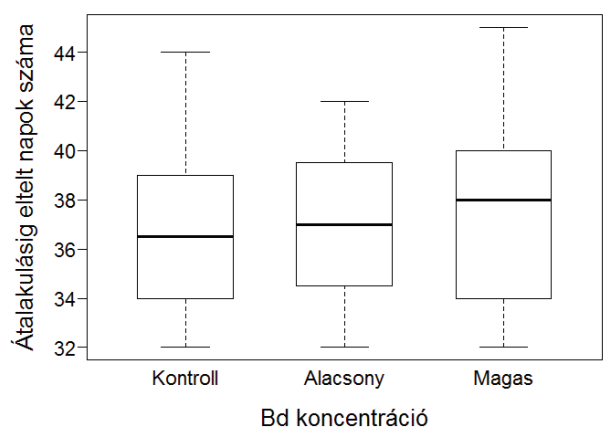

6. ábra. A kezelés hatása a barna varangyok átalakulási idejére.

\section{Túlélés-elemzés}

A Cox-regressziók alapján - a fertőzés intenzitásának figyelembe vételével - a kezelés nem befolyásolta az egyedek túlélését (Wald $\mathrm{Chi}^{2}=2,39$; kezelés: $\mathrm{df}=2$; $P=0,3$; fertőzési intenzitás: $\mathrm{df}=1 ; P=1 ; 7$. ábra). 


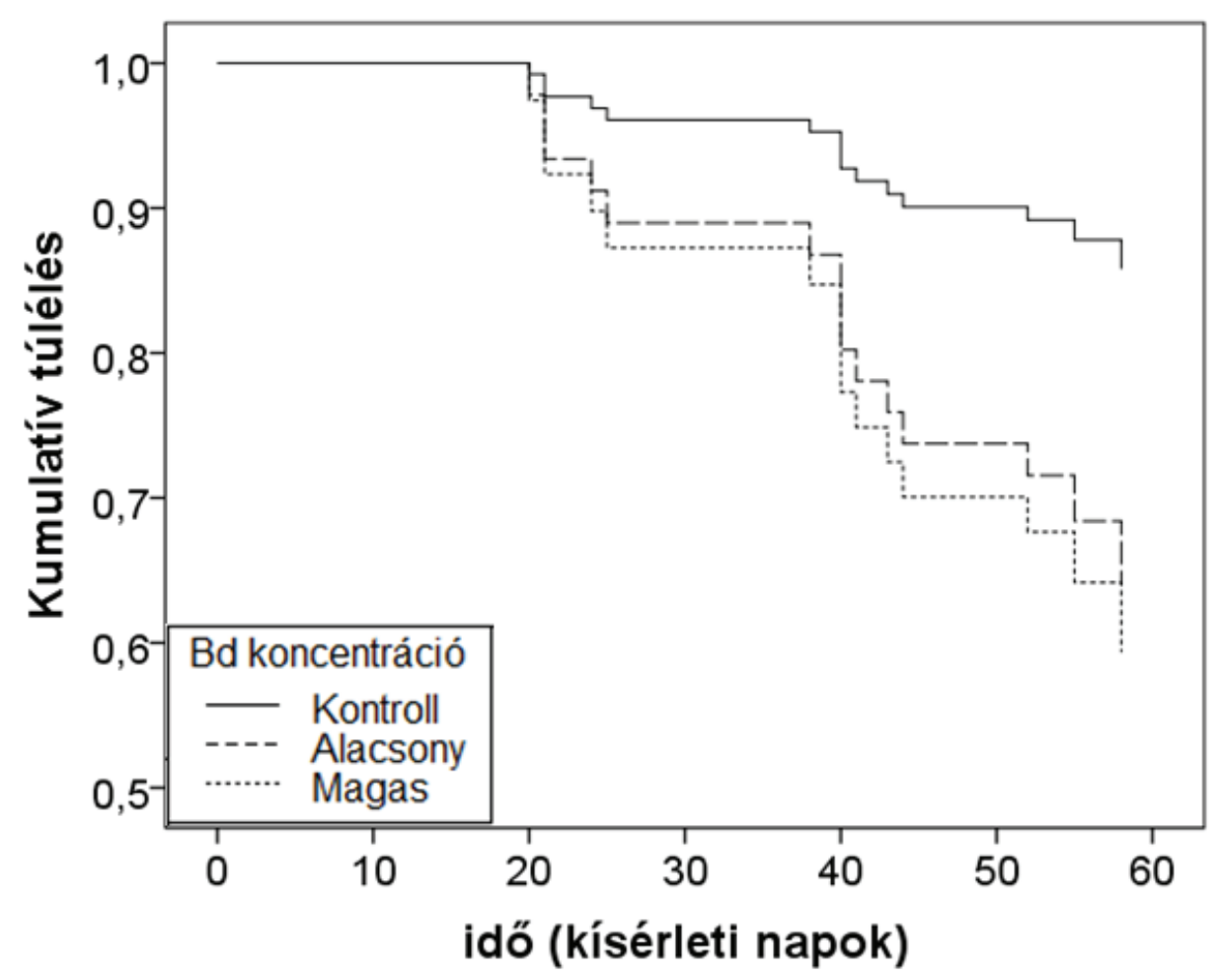

7. ábra. Barna varangyok túlélése a kezelések függvényében. A Bd-fertőzés hatása nem volt szignifikáns.

\section{Értékelés}

Eredményeink alapján úgy tünik, hogy a magas virulenciájú Bd GPL törzzsel szemben a hazai populációkból származó erdei béka egyedek korai életszakaszukban magas rezisztenciával, a barna varangyok pedig magas toleranciával rendelkeznek (terminológia: Woodhams et al. 2011), mivel előbbieken szinte meg sem tudott telepedni a kórokozó, míg utóbbiak nagymértékben fertőződtek, de ennek letális vagy szubletális hatását nem tapasztaltuk.

A barna varangyokon végzett túlélés-elemzésből kiderült, hogy a kezeléseknek és a fertőzési intenzitásnak sem volt szignifikáns hatása a túlélésre, tehát a gomba jelenléte nem növelte meg a halálozás valószínúségét a spontán pusztuláshoz képest, annak ellenére, hogy a fertőződés már az alacsony koncentrációjú kezelésnél is kimutatható volt. A kezelésnek sem önmagában, sem pedig az átalakulás idejével interakcióban nem volt szignifikáns hatása a testtömegre. Ezek alapján a 
fertőződés negatív hatásainak kivédése, legalábbis az általunk vizsgált korai életszakaszban nem jár jelentős energetikai költséggel.

Az erdei béka érzékenységét tudomásunk szerint elsőként vizsgáltuk meg kontrollált körülmények között. A fertőzés intenzitása rendkívül alacsony volt, és a Bd-vel összefüggő mortalitást sem mutattunk ki. A magas dózisú kezelésben nagyobbak voltak az egyedek, de ez a hatás marginálisan nem szignifikánsnak bizonyult. Elképzelhető, hogy a több kórokozónak kitett egyedek több táplálékot fogyasztottak, hogy forrásokat halmozzanak fel, melyek felhasználásával növelhetik védekezésük hatékonyságát. Az átalakulásig eltelt időt egyik fajnál sem befolyásolta a Bd jelenléte, ez alapján a fertőződés az egyedfejlődésbe allokálható energia mennyiségét nem csökkenti.

Kísérletünkben a rezisztenciát és toleranciát egy magas virulenciájú Bd törzszsel szemben mutattuk ki, mely a spanyolországi kétéltüállományokban (Bosch \& Martínez-Solano 2006, Garner et al. 2009) és a barna varangy nagy-britanniai állományaiból származó egyedeknél bizonyítottan nagymértékü pusztulást okozott (T. W. Garner, személyes közlés). Ez alapján valószínű, hogy nem csak a jelenlévő Bd-törzs alacsonyabb virulenciája, hanem az egyedek magasabb ellenálló-képessége is segíti a vizsgált fajok hazai populációit.

Köszönetnyilvánitás - Köszönjük Sendula Tímeának és Szederkényi Márknak a kísérlet kivitelezésében, Bókony Veronikának a statisztikai elemzésekben nyújtott segítségét, Trenton W. J. Garner-nek, hogy rendelkezésünkre bocsátotta a Bd tenyészetet, és a Pilisi Parkerdő Zrt.-nek, hogy engedélyezte útjainak használatát. Az állatok gyüjtését, tartását és hasznosítását a Pest Megyei Kormányhivatal Környezetvédelmi és Természetvédelmi Föosztálya engedélyezte (PE/KTF/3596-8/2016; PE/KTF/3596-7/2016), a kísérletet az MTA ATK NÖVI Munkahelyi Állatkísérleti Bizottsága jóváhagyta. Kutatásunk az MTA Lendület Programjának (MTA, LP2012-24/2012) és egy EU FP7 Marie Curie Career Integration Grant-jának (PCIG13-GA-2013-631722) támogatásával valósult meg.

\section{Irodalomjegyzék}

Baláž, V., Vörös, J., Civiš, P., Vojar, J., Hettyey, A., Sós, E., Dankovics, R., Jehle, R., Christiansen, D. G., Clare, F., Fisher, M. C., Garner, T. W. J. \& Bielby, J. (2014): Assessing Risk and Guidance on Monitoring of Batrachochytrium dendrobatidis in Europe through Identification of Taxonomic Selectivity of Infection. - Conserv. Biol. 28: 213-223. doi: http://dx.doi.org/10.1111/cobi.12128 Berger, L., Speare, R., Daszak, P., Green, D. E., Cunningham, A. A., Goggin, C. L., Slocombe, R., Ragan, M. A., Hyatt, A. D., McDonald, K. R., Hines, H. B., Lips, K. R., Marantelli, G. \& Parkes, H. (1998): Chytridiomycosis causes amphibian mortality associated with population declines in the rain forests of Australia and Central America. - Proc. Natl. Acad. Sci. 95: 9031-9036.

Bosch, J. \& Martínez-Solano, I. (2006): Chytrid fungus infection related to unusual mortalities of Salamandra salamandra and Bufo bufo in the Penalara Natural Park, Spain. -Oryx 40: 84-89. 
Bosch, J., Martínez-Solano, I. \& García-París, M. (2001): Evidence of a chytrid fungus infection involved in the decline of the common midwife toad (Alytes obstetricans) in protected areas of central Spain. - Biol. Conserv. 97: 331-337. doi: http://dx.doi.org/10.1016/S0006-3207(00)00132-4

Boyle, D. G., Boyle, D. B., Olsen, V., Morgan, J. A. T. \& Hyatt, A. D. (2004): Rapid quantitative detection of chytridiomycosis (Batrachochytrium dendrobatidis) in amphibian samples using real-time Taqman PCR assay. - Dis. Aquat. Organ. 60: 141-148. doi: http://dx.doi.org/10.3354/ dao060141

Garner, T.W.J., Walker, S., Bosch, J., Leech, S., Marcus Rowcliffe, J., Cunningham, A. A. \& Fisher, M. C. (2009): Life history tradeoffs influence mortality associated with the amphibian pathogen Batrachochytrium dendrobatidis. - Oikos 118: 783-791. doi: http://dx.doi.org/10.1111/j.16000706.2008.17202.x

Gosner, K. L. (1960): A Simplified Table for Staging Anuran Embryos and Larvae with Notes on Identification. - Herpetologica 16: 183-190.

Mendelson, J. R., Lips, K. R., Gagliardo, R. W., Rabb, G. B., Collins, J. P., Diffendorfer, J. E., Daszak, P. D. R. I., Zippel, K. C., Lawson, D. P., Wright, K. M., Stuart, S. N., Gascon, C., Silva, H. R. da, Burrowes, P. A., Joglar, R. L., Marca, E. L., Lötters, S., Preez, L.H. du, Weldon, C., Hyatt, A., Rodriguez-Mahecha, J. V., Hunt, S., Robertson, H., Lock, B., Raxworthy, C. J., Frost, D. R., Lacy, R. C., Alford, R. A., Campbell, J. A., Parra-Olea, G., Bolaños, F., Domingo, J. J. C., Halliday, T., Murphy, J. B., Wake, M. H., Coloma, L. A., Kuzmin, S. L., Price, M. S., Howell, K. M., Lau, M., Pethiyagoda, R., Boone, M., Lannoo, M. J., Blaustein, A. R., Dobson, A., Griffiths, R. A., Crump, M. L., Wake, D. B. \& Brodie, E. D. (2006): Confronting Amphibian Declines and Extinctions. - Science 313: 48-48. doi: http://dx.doi.org/10.1126/science.1128396

Skerratt, L. F., Berger, L., Speare, R., Cashins, S., McDonald, K. R., Phillott, A. D., Hines, H. B.\& Kenyon, N. (2007): Spread of Chytridiomycosis Has Caused the Rapid Global Decline and Extinction of Frogs. - EcoHealth 4: 125. doi: http://dx.doi.org/10.1007/s10393-007-0093-5

Van Rooij, P., Martel, A., Haesebrouck, F. \& Pasmans, F. (2015): Amphibian chytridiomycosis: a review with focus on fungus-host interactions. - Vet. Res. 46: 137. doi: http://dx.doi.org/10.1186/ s13567-015-0266-0

Woodhams, D. C., Bosch, J., Briggs, C. J., Cashins, S., Davis, L. R., Lauer, A., Muths, E., Puschendorf, R., Schmidt, B. R., Sheafor, B. \& Voyles, J. (2011): Mitigating amphibian disease: strategies to maintain wild populations and control chytridiomycosis. - Front. Zool. 8: 8. doi: http:// dx.doi.org/10.1186/1742-9994-8-8

\section{Internetes hivatkozások:}

http1: http://www.bd-maps.net/surveillance/, utolsó megtekintés időpontja: 2017.03.16. 


\title{
Susceptibility and sensitivity to chytridiomycosis of two anuran species native to Hungary
}

\author{
Tamás Drexler ${ }^{1,2}$, János Ujszegi², Márk Z. Németh ${ }^{3}$, Judit Vörös ${ }^{4}$ \\ and Attila Hettyey ${ }^{2}$ \\ ${ }^{1}$ Department of Ecology, Institute of Biology, University of Veterinary, \\ H-1078 Budapest, Rottenbiller u. 50, Hungary \\ ${ }^{2}$ Lendület Evolutionary Ecology Research Group, Plant Protection Institute, Centre for \\ Agricultural Research, Hungarian Academy of Sciences, \\ H-1022 Budapest, Herman Ottó út 15, Hungary \\ ${ }^{3}$ Department of Plant Pathology, Plant Protection Institute, Centre for Agricultural \\ Research, Hungarian Academy of Sciences, \\ H-1022 Budapest, Herman Ottó út 15, Hungary \\ ${ }^{4}$ Hungarian Natural History Museum, \\ H-1088 Budapest, Baross u. 13, Hungary \\ e-mail:dretom93@gmail.com
}

The causal agent of chytridiomycosis, Batrachochytrium dendrobatidis is known to be present in the Carpathian Basin, however, there is no evidence for population declines accountable to this disease in Hungarian populations. This may partly be explained by the high tolerance of local amphibian populations. In our study, we experimentally infected larval individuals of the common toad (Bufo bufo) and the agile frog (Rana dalmatina) with a highly virulent, globally distributed Bd strain. We observed if there are any direct or indirect effects of exposure two weeks after metamorphosis. We did not observe significantly decreased survival, body mass or development rate resulting from exposure to Bd in either species. However, infection intensity was higher in toads than in frogs by an order of magnitude. Our results suggest that in Hungary, common toads are highly tolerant to Bd while agile frogs are rather resistant against this disease.

Keywords: chytridiomycosis, agile frog, common toad, tolerance, resistance 